\title{
Combined effect of silica dust and tobacco smoking on mortality from chronic obstructive lung disease in gold miners
}

\author{
Eva Hnizdo
}

\begin{abstract}
A sample of 2209 white South African gold miners aged 45-54 between 1968-71, who started mining exposure during 1936-43, was investigated from 1968-71 to 30 December 1986. The effect of silica dust and tobacco smoking on mortality from chronic obstructive lung disease (COLD) was assessed. The relative risk (RR) for dust exposure before 1950 was estimated as $2 \cdot 5$ (95\% confidence interval (CI) $1.5-$ $4 \cdot 2$ ), for 10 units of 1000 particle-years. The combined effect of dust exposure before 1950 and years of cigarette smoking on mortality from COLD was best estimated by the multiplicative model, indicating that the two exposures act synergistically. All those that died of the disease were smokers. According to the estimates of attributable risk about $5 \%$ of the deaths from COLD were from the effect of dust, $34 \%$ were from smoking, and $59 \%$ were from the combined effect of dust and smoking. In conclusion, the results indicate that workers exposed to silica dust who smoke are at higher risk of dying from COLD than smokers not exposed to silica dust, as the two exposures act synergistically in causing COLD.
\end{abstract}

South African gold miners are exposed to dust with a high concentration of crystalline silica. About $60^{\circ}{ }_{0}$ of the virgin rock is silica and about $30^{\circ}$ o free silica is present in the respirable dust. ${ }^{1}$ The average concentrations of respirable silica representative of the gold mining industry range from 0.05 to $0.84 \mathrm{mg} / \mathrm{m}^{3}$ for underground air. ${ }^{2}$ Tobacco smoking is also highly prevalent among the gold miners; about $70 \%$ of the white miners were current smokers. ${ }^{34}$

The epidemiological and experimental evidence supports the hypothesis that both exposuresnamely silica dust and tobacco smoking-increase

Epidemiology Research Unit, Medical Bureau for Occupational Diseases, PO Box 4584, Johannesburg 2000, South Africa

E Hnizdo the prevalence of respiratory impairments. ${ }^{4-7}$ A question then arises as to whether the impairment in lung function associated with exposure to silica dust leads to increased mortality from COLD, and what is the relative contribution of dust and tobacco smoking to it.

In a previous study of mortality in middle aged South African gold miners a standardised mortality ratio (SMR) of $166\left(95^{\circ}{ }_{0}\right.$ confidence interval (CI) 108-243) and a relative risk (RR) of 2.48 per 10000 particle-years $(p<0.03)$ were reported for death from COLD. ${ }^{8}$

The objective of this study was to examine the individual and combined effects of exposure to gold mining dust and tobacco smoking on mortality from COLD. The questions asked were: (1) Is exposure to silica dust related to mortality from COLD? (2) What is the shape of the dose response curve? (3) Is the combined effect of silica dust and smoking additive or synergistic? (4) What is the relative contribution of silica dust and tobacco smoking to the risk of death from COLD?

\section{Materials and methods}

STUDY SUBJECTS

All the white gold miners who were included in a 1968-71 study of $\mathrm{COLD}^{4}$ were followed up to 30 December 1986 when their vital state was established. The study subjects consisted of miners attending the Medical Bureau for Occupational Diseases (MBOD) during the four years 1968-71 for a medical examination and who fulfilled the following criteria: (1) MBOD number within the range B9000 to C8999; (2) age 45-54; (3) minimal underground service 10 years; (4) at least 20 years residence in South Africa; (5) less than two years service in mines other than gold mines. An annual medical examination is compulsory for all miners working in dusty occupations. Miners who retired but attended the medical examination because they were seeking compensation were also included in the selection procedure. ${ }^{4}$

The vital state of the cohort was established from the records of the Provident Fund (gold miners' pension fund), from medical files, and from the 
Department of Interior. A list of names and dates of birth of all the 2209 miners was sent to the Provident Fund and to the Department of Interior, where the miners' vital state was established. The copies of the death registration certificates were obtained from the Department of Interior. Of the 945 miners who died during the follow up period, $794(84.0 \%)$ had had necropsy examinations performed at the National Center for Occupational Health (NCOH). Medical files were available on all of the dead miners. The cause of death was established from the best available information by an experienced specialist physician who was not aware of the purpose of the study and did not consider the exposure to dust or smoking habits when making the diagnosis. The 9 th revision of the International Classification of Diseases (ICD) code was used, and COLD was coded as present when the person evidently died of bronchitis (ICD = $491, \mathrm{n}=1$ ), emphysema (ICD $=492, \mathrm{n}=15$ ), or chronic airways obstruction $(\mathrm{ICD}=496, \mathrm{n}=50)$.

\section{MINING EXPOSURE}

The occupations were classified on the basis of measured dust counts into 11 groups for which the average respirable dust count was calculated. ${ }^{9}$ For every miner the number of shifts worked in each occupation was weighted by the mean dust count (expressed in respirable dust) for that occupational group. The cumulative dust counts were calculated to the end of the follow up period and converted into particle-years. Also, the original coding of the dust exposures was done in such a way that exposure for each decade-namely, the 1940s, 50s, 60s, and 70scould be calculated.

\section{SMOKING HABITS}

Full details of smoking habits were obtained during the 1968-71 examination by means of a questionnaire on smoking, and the reliability of the answers was checked against smoking histories recorded on the medical files kept at the MBOD. Tobacco consumption was evaluated in terms of number of cigarettes smoked each day, years of smoking (cigarettes), cigarette equivalent pack-years, and as a categorised smoking variable SMOKEC with categories 0 to 4 for non-smoker, ex-smoker, and current smoker $(<20,20-39$ and $\geqslant 40$ pack-years).

\section{LUNG FUNCTION TESTS AND RESPIRATORY SYMPTOMS} AND SIGNS

The information collected during the 1968-71 examination relating to respiration included forced vital capacity (FVC), forced expiratory volume $\left(\mathrm{FEV}_{1}\right)$, and forced mid-expiratory flow $\left(\mathrm{FEF}_{25-75^{\circ}}\right)$, assessment of the presence of simple chronic bronchitis by means of a questionnaire and measured mucus, and the presence of rhonchi.

\section{METHOD OF ANALYSIS}

The dose response relation between age specific mortality risks and rates for COLD and the individual exposures, dust and smoking, and the combined effect of the two exposures were evaluated by means of the general RR model using firstly, a nested case-referent study design and conditional maximum likelihood method of analysis; secondly, the cohort data and Poisson model.

A nested age matched case-referent study design was used so as to select the exposure variables most strongly associated with the outcome. For each case of a miner who died of COLD, a set of six referents was selected at random from those miners who were born closest to the date of birth of the case (within one year), and had survived the case in age. ${ }^{1011}$ The general RR model proposed by Breslow and Storer, ${ }^{12}$ namely

$$
\begin{gathered}
\log (\mathrm{RR})=\left\{\left[1+\beta_{1}(\text { dust })+\right.\right. \\
\left.\left.\beta_{2} \text { (smoking) }\right]^{i}-1\right\} / \lambda, \lambda \neq 0 \\
\log (\mathrm{RR})=\log \left\{1+\beta_{1} \text { (dust) }+\right. \\
\beta_{2} \text { (smoking) } \lambda \lambda=0
\end{gathered}
$$

was applied to evaluate the shape of the dose response curve ${ }^{13}$ and to evaluate the combined effect of dust and smoking. The goodness of fit of the model was evaluated by the $\log$ likelihood ratio $(-2 \log L)$ or the deviance statistic. ${ }^{14}$ The mixture parameter, $\lambda$, established from the best fitting model was used to determine whether the combined effect of two exposure variables is additive $(\lambda=0)$ or multiplicative $(\lambda=1)$ or somewhere in between.

In the analysis of cohort data the effect measure is the mortality and the Poisson model can be used for making statistical inferences about rates. ${ }^{14}$ In this study the method of analysis of cohort data for the assessment of the individual and combined effects as described by Lubin and Gaffey ${ }^{15}$ and Breslow and Day ${ }^{14}$ was used.

The data were cross classified by five age categories $(45-49,50-54,55-59,60-64$, and 65-69), five calendar year at risk categories $(<1970,1970-4$, 1975-9, 1980-4, and 1984 onwards), four years of smoking categories (CYSMC) $(<10,10-19,20-29$, $\geqslant 30$ ), and four categories for particle-years $/ 1000$ cumulated to the end of $1949(\mathrm{CD} 40 \mathrm{C})(<5,5-9,10$ $14, \geqslant 15)$. Thus using the notation of Breslow and Day ${ }^{14}$ there are I categories for dust, J for smoking, and $K$ categories for the nuisance effect of age and year at risk combined together. For dust $i$, smoking $j$, and age and year $k$, the data in the $(i, j, k)$ th cell consist of the observed number of deaths $d_{i j k}$ from COLD, person-years $N_{i j k}$, the mortality rates $h_{i j k}=d_{i j k} / N_{i j k}$, and the mean values for the exposure variables denoted as $\underline{X}_{\mathrm{ijk}}=\left(\mathbf{X}_{1 \mathrm{ijk}}, \mathbf{X}_{2 \mathrm{ijk}}\right)$ where $\mathbf{X}_{1 \mathrm{ijk}}$ represents the dust variable and $X_{2 \mathrm{ijk}}$ represents the smoking variable. The expected mortality within each ijk cell, $\hat{h}_{i j k}$, can be estimated with a following function 


$$
\hat{\mathrm{h}}_{\mathrm{ijk}}=\mathrm{h}_{0 \mathrm{k}} \cdot \mathbf{R}\left(\underline{\mathrm{X}}_{\mathrm{ijk}} ; \beta\right) \text {, }
$$

where $h_{0 k}$ denotes the age and year specific disease rate at $R(0)=1$, and $R\left(\underline{X}_{i j k}\right)$ is the relative risk given by a specific risk function. The relative risk function used was as specified in equation (1). The equation (2) was estimated by the maximum log likelihood function given in Breslow and Day ${ }^{14}$ (page 133). The computer program GLIM and the general minimisation program MINUIT $^{16}$ were used to fit the models.

The person-years in each $(i, j, k)$ th cell and the age and year at risk adjusted SMRs given in table 3 have been calculated according to a method described by Frome and Checkoway. ${ }^{17}$

\section{Results}

NESTED CASE-REFERENT STUDY

Table 1 shows the case-referent comparison for personal characteristics, exposure to dust, smoking habits, lung function tests, and respiratory signs and symptoms as measured during the 1970 examination. The cases had significantly lower body weight than the referents. The body weights of the two groups were found to be the same at the initial medical examination at around 20 years of age, and subsequently the referents increased their weight at a higher rate than did the cases. The cases had significantly lower lung function tests $\left(\mathrm{FEV}_{1}, \mathrm{FVC}\right.$, $\left.\mathrm{FEF}_{25-75^{\prime \prime},}\right)$ and higher prevalences of respiratory symptoms and signs (simple chronic bronchitis, measured mucus $\geqslant 2 \mathrm{ml}$, and rhonchi) than the referents at the time of the 1970 examination.

The cases had higher exposure to dust up to the end of the 1960s and thereafter the exposure to dust for the referents became higher. The case-referent differences in particle-years for the 1940 s reached significance $(\mathrm{p}=0.024)$. The actual years of exposure did not differ. In order to establish the particle-years that were most strongly associated with the mortality from COLD, the cumulative particle-years from the start of the gold mining exposure to 1949 (CD40), to 1959 (CD50), to 1969 (CD60), and the total to the start of follow up (196971) (CDTS) were examined individually in a conditional logistic regression model, in which the effect of smoking was adjusted. The best predictor of dust

Table 1 Comparison of COLD cases and age matched referents

\begin{tabular}{|c|c|c|c|c|c|}
\hline \multirow{2}{*}{$\begin{array}{l}\text { Characteristic } \\
\text { Year of birth } \\
\text { Start of follow up } \\
\text { Body weight }(\mathrm{kg}) \\
\text { Body height }(\mathrm{cm}) \\
\text { Age at death }(\mathrm{y})\end{array}$} & \multicolumn{2}{|c|}{ Cases mean $(S D)(n=66)$} & \multicolumn{2}{|c|}{ Referents mean $(S D)(n=396)$} & \multirow{2}{*}{$\begin{array}{l}\text { p Value } \\
0.99 \\
0.99 \\
0.0001 \\
0.97\end{array}$} \\
\hline & $\begin{array}{c}1918 \cdot 32 \\
1969 \cdot 21 \\
74 \cdot 3 \\
176 \cdot 7 \\
61 \cdot 8\end{array}$ & $\begin{array}{l}(2 \cdot 34) \\
(1 \cdot 12) \\
(11 \cdot 3) \\
(6 \cdot 1) \\
(5 \cdot 0)\end{array}$ & $\begin{array}{c}1918 \cdot 31 \\
1969 \cdot 28 \\
81 \cdot 4 \\
176 \cdot 8\end{array}$ & $\begin{array}{l}(2 \cdot 34) \\
(1 \cdot 07) \\
(11 \cdot 7) \\
(5 \cdot 7)\end{array}$ & \\
\hline $\begin{array}{l}\text { Gold mining exposure: } \\
\text { Particle-years to } 1949 \\
1950-9 \\
1960-9 \\
1969-\text { start }^{\star} \\
\text { Start-1986 } \\
\text { Years to } 1949 \\
1950-9 \\
1960-9 \\
1969-\text { start } \\
\text { Start-1986 }\end{array}$ & $\begin{array}{r}11250 \\
11611 \\
9566 \\
259 \\
2630 \\
8 \cdot 1 \\
8 \cdot 7 \\
7 \cdot 5 \\
0 \cdot 2 \\
2 \cdot 2\end{array}$ & $\begin{array}{l}(4983) \\
(4134) \\
(4192) \\
(543) \\
(4043) \\
(3 \cdot 1) \\
(1.9) \\
(2 \cdot 4) \\
(0.5) \\
(3.0)\end{array}$ & $\begin{array}{r}9735 \\
10545 \\
8891 \\
280 \\
4015 \\
7 \cdot 6 \\
8.6 \\
7 \cdot 4 \\
0.2 \\
3.2\end{array}$ & $\begin{array}{l}(5043) \\
(4542) \\
(5165) \\
(562) \\
(6637) \\
(3.0) \\
(1.9) \\
(2 \cdot 7) \\
(0.4) \\
(2.9)\end{array}$ & $\begin{array}{l}0.024 \\
0.075 \\
0.315 \\
0.770 \\
0.022 \\
0.21 \\
0.84 \\
0.80 \\
0.97 \\
0.012\end{array}$ \\
\hline $\begin{array}{l}\text { Smoking habits: } \\
\text { Cigarettes (No/day) } \\
\text { Years smoked } \\
\text { Cigarettes (pack-years) } \\
\text { Cigarette equivalents (pack-years) } \\
\left.\text { Never smoked (No }\left({ }^{\circ}{ }_{0}\right)\right) \\
\left.\text { Ex-smoker (No }\left({ }^{\circ}\right)\right) \\
\text { Current smoker }\left(\text { No }_{0}\left({ }^{\circ}{ }_{0}\right)\right)\end{array}$ & $\begin{array}{c}18 \cdot 2 \\
28 \cdot 5 \\
26 \cdot 5 \\
31 \cdot 3 \\
0 \\
11 \\
55\end{array}$ & $\begin{array}{l}(9 \cdot 5) \\
(6 \cdot 7) \\
(15 \cdot 4) \\
(16 \cdot 3) \\
(0.0 \%) \\
(16.7 \%) \\
(83.3 \%)\end{array}$ & $\begin{array}{c}15 \cdot 2 \\
21 \cdot 6 \\
19 \cdot 8 \\
23 \cdot 6 \\
53 \\
89 \\
254\end{array}$ & $\begin{array}{l}(10 \cdot 8) \\
(11 \cdot 7) \\
(17 \cdot 3) \\
(18 \cdot 2) \\
(13 \cdot 4 \%) \\
(22.5 \%) \\
(64 \cdot 1 \%)\end{array}$ & $\begin{array}{l}0.02 \\
0.0001 \\
0.0004 \\
0.002 \\
0.0001 \dagger\end{array}$ \\
\hline $\begin{array}{l}\text { Lung function tests: } \\
\text { FEV, } \\
\text { FVC } \\
\text { FEF }_{25-75 . .}\end{array}$ & $\begin{array}{l}1.98 \\
3.98 \\
1.09\end{array}$ & $\begin{array}{l}(0.83) \\
(0.85) \\
(0.77)\end{array}$ & $\begin{array}{l}3 \cdot 10 \\
4 \cdot 40 \\
2 \cdot 75\end{array}$ & $\begin{array}{l}(0 \cdot 72) \\
(0 \cdot 72) \\
(1 \cdot 30)\end{array}$ & $\begin{array}{l}0.0001 \\
0.0001 \\
0.0001\end{array}$ \\
\hline $\begin{array}{l}\text { Respiratory symptoms and signs: } \\
\text { Rhonchi }\left(\text { No }\left(\mathrm{o}_{\mathrm{o}}\right)\right) \\
\text { Bronchitis }(\mathrm{No}(\%)) \\
\text { Mucus } \geqslant 2 \mathrm{ml}(\mathrm{No}(\%))\end{array}$ & $\begin{array}{l}31 \\
38 \\
34\end{array}$ & $\begin{array}{l}(47 \cdot 0 \%) \\
(57 \cdot 6 \%) \\
(51.5 \%)\end{array}$ & $\begin{array}{r}89 \\
147 \\
152\end{array}$ & $\begin{array}{l}(22.5 \%) \\
(31.8 \%) \\
(38.6 \%) \ddagger\end{array}$ & $\begin{array}{l}0.0001 \\
0.01 \\
0.04\end{array}$ \\
\hline
\end{tabular}

* Start of the follow up study.

$+\chi^{2}$ test for trend.

$\ddagger$ Two subjects did not have sputum tested. 
Table 2 Distribution of cases and referents according to dust particle-years (CD40C) and cigarette-years smoked (CYSMC)

\begin{tabular}{|c|c|c|c|c|c|c|c|}
\hline \multirow{2}{*}{$\begin{array}{l}\text { Dust* } \\
\text { (CD40 C) }\end{array}$} & \multirow{2}{*}{$\begin{array}{l}\text { Death } \\
\text { from COLD }\end{array}$} & \multicolumn{4}{|c|}{ Cigarette-years smoked (CYSMC) } & \multirow[b]{2}{*}{ Total No } & \multirow{2}{*}{$\begin{array}{l}\text { OR† } \\
(95 \% \text { CI })\end{array}$} \\
\hline & & 2 & 16 & 26 & 34 & & \\
\hline 3.99 & $\begin{array}{l}\text { Yes } \\
\text { No } \\
(\mathrm{OR}) \ddagger\end{array}$ & $\begin{array}{c}0 \\
19 \\
(1 \cdot 0)\end{array}$ & $\begin{array}{l}0 \\
9 \\
(2 \cdot 1)\end{array}$ & $\begin{array}{l}3 \\
41 \\
(3 \cdot 3)\end{array}$ & $\begin{array}{c}2 \\
11 \\
(8 \cdot 5)\end{array}$ & $\begin{array}{c}5 \\
80 \\
(1 \cdot 0)\end{array}$ & $1 \cdot 0$ \\
\hline $7 \cdot 44$ & $\begin{array}{l}\text { Yes } \\
\text { No } \\
(\mathrm{OR}) \ddagger\end{array}$ & $\begin{array}{c}1 \\
21 \\
(2 \cdot 7)\end{array}$ & $\begin{array}{c}2 \\
15 \\
(6 \cdot 3)\end{array}$ & $\begin{array}{c}9 \\
58 \\
(6 \cdot 3)\end{array}$ & $\begin{array}{l}8 \\
37 \\
(8 \cdot 8)\end{array}$ & $\begin{array}{c}20 \\
131 \\
(2 \cdot 4)\end{array}$ & $\begin{array}{l}2 \cdot 5 \\
(0 \cdot 9-6 \cdot 9)\end{array}$ \\
\hline $12 \cdot 35$ & $\begin{array}{l}\text { Yes } \\
\text { No } \\
(\mathrm{OR})_{\ddagger}\end{array}$ & $\begin{array}{c}0 \\
30 \\
(0 \cdot 6)\end{array}$ & $\begin{array}{c}2 \\
18 \\
(5 \cdot 3)\end{array}$ & $\begin{array}{c}12 \\
47 \\
(10 \cdot 3)\end{array}$ & $\begin{array}{c}9 \\
26 \\
(14 \cdot 0)\end{array}$ & $\begin{array}{c}23 \\
121 \\
(3 \cdot 0)\end{array}$ & $\begin{array}{l}3 \cdot 3 \\
(1 \cdot 2-9 \cdot 4)\end{array}$ \\
\hline $17 \cdot 58$ & $\begin{array}{l}\text { Yes } \\
\text { No } \\
(\mathrm{OR})_{\ddagger}\end{array}$ & $\begin{array}{c}0 \\
14 \\
(1 \cdot 3)\end{array}$ & $\begin{array}{c}1 \\
8 \\
(6 \cdot 9)\end{array}$ & $\begin{array}{c}7 \\
23 \\
(12 \cdot 5)\end{array}$ & $\begin{array}{c}10 \\
19 \\
(21 \cdot 0)\end{array}$ & $\begin{array}{l}18 \\
64 \\
(4 \cdot 5)\end{array}$ & $\begin{array}{l}5 \cdot 3 \\
(1 \cdot 8-15 \cdot 9)\end{array}$ \\
\hline $\begin{array}{l}\text { Total } \\
\text { OR }{ }^{\dagger} \\
\left(95^{\circ}, \mathrm{CI}\right)\end{array}$ & $\begin{array}{l}\text { Yes } \\
\text { No } \\
(\mathrm{OR}) \ddagger\end{array}$ & $\begin{array}{c}1 \\
84 \\
(1 \cdot 0) \\
1 \cdot 0\end{array}$ & $\begin{array}{l}5 \\
50 \\
(8 \cdot 4) \\
8 \cdot 0 \\
(0 \cdot 9-69 \cdot 7)\end{array}$ & $\begin{array}{l}31 \\
169 \\
(15 \cdot 4) \\
15 \cdot 8 \\
(2 \cdot 1-118 \cdot 0)\end{array}$ & $\begin{array}{l}29 \\
93 \\
(26 \cdot 2) \\
32 \cdot 3 \\
(4 \cdot 2-248 \cdot 2)\end{array}$ & $\begin{array}{r}66 \\
396\end{array}$ & \\
\hline
\end{tabular}

^Mean dust particle-years/1000 before 1950 .

tORs adjusted for age.

+Unadjusted OR.

was $\operatorname{CD} 40\left(\mathrm{X}_{\mathrm{LR}}^{2}=5.9 ; \mathrm{df}=1 ; \mathrm{p}=0.015\right)$ and this variable was used to assess the combined effect of dust and smoking. It was noted that the log likelihood ratio for dust did not change by inclusion of smoking into the model, and vice versa.

As expected, the cases had significantly higher consumption of tobacco than the referents. In a preliminary analysis of the case-referent data, all the variables available on smoking were related to mortality from COLD by means of the stepwise logistic regression model. The smoking variables found to be most strongly related to death from COLD were years of cigarette smoking (CYSM), the categorised smoking variable (SMOKEC), cigarette equivalent pack-years (this includes pipe smoking), and cigarette pack-years, in that order. The above smoking variables were then included individually in a logistic model in which the effect of dust was adjusted and the best predictor for smoking was selected according to the goodness of fit criteria. As the model with years of cigarette smoking had the highest log likelihood ratio, this variable was used in the analysis of the combined effect. The years of smoking and the categorised smoking variable (SMOKEC) take into account whether a person stopped smoking or not, and this may be the reason why these variables were more strongly related to death from COLD than cigarette or cigarette equivalent pack-years.

Table 2 shows the two way frequency distribution of the cases and referents for categorised particleyears/1000 up to 1949 (CD40C) $(<5,5-9,10-14$, $\geqslant 15$ ), and categorised years of cigarette smoking (CYSMC) $(<10,10-19,20-29, \geqslant 30)$. The mean values given in table 2 for each range were used to estimate the shape of the dose response curve. ${ }^{18}$ The marginal observed odds ratios (ORs) displayed a significant increasing trend for dust particle-years $\left(\chi_{(1)}^{2}=8 \cdot 9, \mathrm{p}=0.003\right)$ and for cigarette years of smoking $\left(\chi_{(1)}^{2}=22.2, \mathrm{p}<0.0001\right)$. The age adjusted marginal ORs, estimated from the conditional ligistic regression by means of $(0,1)$ indicator variables, also confirmed a significant dose response relation between death from COLD and the individual exposure variables.

The estimated ORs have a large error attached, and consequently the models applied in order to assess the shape of the dose response curve (equation (1) with only one exposure variable) fitted equally well. For CD40C the maximum log likelihood displayed an insignificant change when $\lambda$ changed from 0 to $1 \cdot 0$; nevertheless, the model with $\lambda=0$ fitted the data better than the model with $\lambda=1$, suggesting a linear relation. For the continuous particle-years (CD40), the multiplicative model gave a better fit, but again the change in the log likelihood was insignificant, suggesting that for all practical purposes the linear and exponential models fitted equally well. For the categorised years of cigarette smoking (CYSMC) and the continuous variable (CYSM), the best fits were obtained with $\lambda=0.50$ and $\lambda=0.51$. For both variable types, the model with $\lambda=0.5$ gave the best fit, but the likelihood ratio test of $\lambda=0 v \hat{\lambda}=1$ was not statistically significant.

Table 2 shows the risk of dying from COLD for those exposed to various combinations of dust and smoking relative to those exposed to the lowest dust 
Table 3 Numbers of deaths and person-years $(P-Y)$ by dust particle-years (CD40C) and cigarette-years smoked (CYSMC)

\begin{tabular}{|c|c|c|c|c|c|c|c|}
\hline \multirow{2}{*}{$\begin{array}{l}\text { Dust } \\
\text { (CD40C) }\end{array}$} & & \multicolumn{4}{|c|}{ Cigarette-years smoked (CYSMC) } & \multirow[b]{2}{*}{ Total } & \multirow{2}{*}{$\begin{array}{l}R R \S \\
(95 \% C I)\end{array}$} \\
\hline & & $<10$ & $10-19$ & $20-29$ & $\geqslant 30$ & & \\
\hline $5-9$ & $\begin{array}{l}\text { Deaths } \\
\text { P-Y } \\
\text { SMR* } \\
\text { CD40† } \\
\text { CYSM }\end{array}$ & $\begin{array}{c}1 \\
1935 \\
0 \cdot 23 \\
7454 \\
1 \cdot 3\end{array}$ & $\begin{array}{c}2 \\
1487 \\
0.68 \\
7554 \\
16 \cdot 7\end{array}$ & $\begin{array}{c}9 \\
4712 \\
0.97 \\
7141 \\
26 \cdot 2\end{array}$ & $\begin{array}{c}8 \\
2070 \\
1 \cdot 72 \\
7866 \\
33.4\end{array}$ & $\begin{array}{c}20 \\
10204 \\
0.94\end{array}$ & $\begin{array}{l}2 \cdot 49 \\
(0 \cdot 9-6 \cdot 7)\end{array}$ \\
\hline $10-14$ & $\begin{array}{l}\text { Deaths } \\
\text { P-Y } \\
\text { SMR* } \\
\text { CD40† } \\
\text { CYSM+ }\end{array}$ & $\begin{array}{c}0 \\
2024 \\
0 \cdot 00 \\
12242 \\
2 \cdot 1\end{array}$ & $\begin{array}{c}2 \\
1387 \\
0 \cdot 67 \\
12447 \\
16.5\end{array}$ & $\begin{array}{c}12 \\
4048 \\
1 \cdot 51 \\
12219 \\
26.5\end{array}$ & $\begin{array}{c}9 \\
2117 \\
1.92 \\
12234 \\
32.9\end{array}$ & $\begin{array}{c}23 \\
9576 \\
1 \cdot 14\end{array}$ & $\begin{array}{l}3 \cdot 12 \\
(1 \cdot 2-8 \cdot 3)\end{array}$ \\
\hline$\geqslant 15$ & $\begin{array}{l}\text { Deaths } \\
\text { P-Y } \\
\text { SMR* } \\
\text { CD40† } \\
\text { CYSM+ }\end{array}$ & $\begin{array}{c}0 \\
971 \\
0 \cdot 00 \\
17379 \\
2 \cdot 7\end{array}$ & $\begin{array}{c}1 \\
712 \\
0 \cdot 59 \\
18886 \\
15 \cdot 7\end{array}$ & $\begin{array}{c}7 \\
1573 \\
2 \cdot 04 \\
17555 \\
26 \cdot 0\end{array}$ & $\begin{array}{c}10 \\
1092 \\
4 \cdot 25 \\
17944 \\
33 \cdot 6\end{array}$ & $\begin{array}{c}18 \\
4348 \\
1 \cdot 82\end{array}$ & $\begin{array}{l}5 \cdot 30 \\
(2 \cdot 0-14 \cdot 4)\end{array}$ \\
\hline Total & $\begin{array}{l}\text { Deaths } \\
\text { P-Y } \\
\text { SMR }\end{array}$ & $\begin{array}{c}1 \\
6458 \\
0 \cdot 07\end{array}$ & $\begin{array}{r}5 \\
4365 \\
0.54\end{array}$ & $\begin{array}{c}31 \\
13848 \\
1 \cdot 14\end{array}$ & $\begin{array}{c}29 \\
6321 \\
2 \cdot 08\end{array}$ & $\begin{array}{r}66 \\
30992\end{array}$ & \\
\hline $\begin{array}{l}\text { RRß } \\
\left(95^{\circ}{ }_{0} \mathrm{CI}\right)\end{array}$ & & $1 \cdot 0$ & $\begin{array}{l}7 \cdot 29 \\
(0 \cdot 9-62)\end{array}$ & $\begin{array}{l}16 \cdot 15 \\
(2 \cdot 3-118)\end{array}$ & $\begin{array}{l}29 \cdot 18 \\
(4 \cdot 0-214)\end{array}$ & & \\
\hline
\end{tabular}

$\star S M R$ adjusted for the effect of age and year at risk.

+ Mean value for dust particle-years/1000 before 1950 .

+ Mean values for years of cigarette smoking to 1970 examination.

$\$ R R$ adjusted for age, year at risk, and the other exposure.

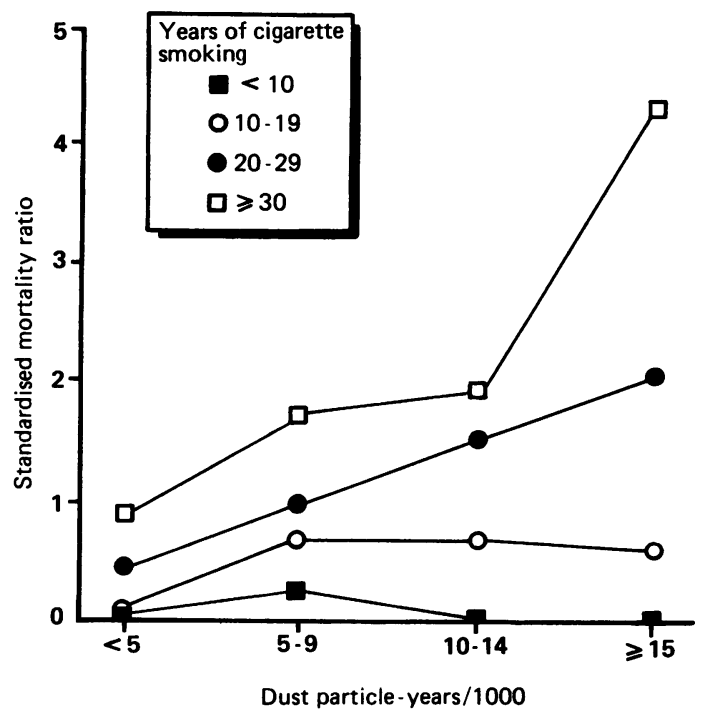

Figure Standardised mortality ratio for chronic obstructive lung disease, according to dust exposure before 1950 and years of cigarette smoking. and smoking level, as estimated by the OR. The calculation was complicated by the zero value in the lowest exposure cell, and thus 0.5 was added to each frequency number. Only one subject died of COLD among those who had smoked cigarettes for less than 10 years, and thus there was no trend with dust for that smoking category; an increasing trend with dust for all the other smoking categories occurred, especially for those miners who smoked for 20 or more years. On inspection of the medical file, it was found that the miner who died of COLD and was coded as smoking for less than 10 years was in fact a pipe smoker for 32 years and consumed on average four ounces of tobacco a week; according to the medical file and questionnaire on smoking he did not smoke cigarettes.

The trend in the OR indicates a synergistic effect. The ORs in the two highest categories for dust and smoking had higher values than would be expected from merely adding the individual effects-for example, $21>8 \cdot 5+1 \cdot 3-1$ and $12 \cdot 5>3.3+1 \cdot 3-1$. The synergistic effect appears to be present for dust categories with more than 10000 particle-years and for those who smoked cigarettes for more than 20 years. 
Table 4 Predicted number of deaths from models with different values of $\lambda$

\begin{tabular}{|c|c|c|c|c|c|c|c|c|}
\hline \multirow{2}{*}{$\begin{array}{l}\text { Dust } \\
\text { (CD40C) }\end{array}$} & \multirow[b]{2}{*}{ Years smoked } & \multirow{2}{*}{\multicolumn{2}{|c|}{$P-Y$ Observed deaths }} & \multicolumn{5}{|c|}{ Estimated No of deaths for given $\lambda$} \\
\hline & & & & 0.0 & $0 \cdot 2$ & 0.5 & 0.6 & $1 \cdot 0$ \\
\hline$<5$ & $\begin{aligned}< & 10 \\
& 10-19 \\
& 20-29 \\
\geqslant & 30\end{aligned}$ & $\begin{array}{r}1528 \\
779 \\
3513 \\
1042\end{array}$ & $\begin{array}{l}0 \\
0 \\
3 \\
2\end{array}$ & $\begin{array}{l}0 \cdot 32 \\
1 \cdot 19 \\
8 \cdot 49 \\
3 \cdot 39\end{array}$ & $\begin{array}{l}0.03 \\
0.31 \\
4 \cdot 16 \\
2.46\end{array}$ & $\begin{array}{l}0.08 \\
0.33 \\
4 \cdot 19 \\
2 \cdot 45\end{array}$ & $\begin{array}{l}0.09 \\
0.32 \\
4.07 \\
2 \cdot 46\end{array}$ & $\begin{array}{l}0 \cdot 18 \\
0 \cdot 35 \\
4 \cdot 08 \\
2 \cdot 46\end{array}$ \\
\hline $5-9$ & $\begin{aligned}< & 10 \\
& 10-19 \\
& 20-29 \\
\geqslant & 30\end{aligned}$ & $\begin{array}{l}1935 \\
1487 \\
4712 \\
2070\end{array}$ & $\begin{array}{l}1 \\
2 \\
9 \\
8\end{array}$ & $\begin{array}{r}0.56 \\
2.40 \\
11.87 \\
6.95\end{array}$ & $\begin{array}{l}0 \cdot 17 \\
1 \cdot 10 \\
8 \cdot 72 \\
7 \cdot 10\end{array}$ & $\begin{array}{l}0 \cdot 23 \\
1.06 \\
8 \cdot 51 \\
7 \cdot 10\end{array}$ & $\begin{array}{l}0 \cdot 24 \\
1 \cdot 01 \\
8 \cdot 28 \\
7 \cdot 18\end{array}$ & $\begin{array}{l}0.34 \\
1.02 \\
8 \cdot 04 \\
7 \cdot 19\end{array}$ \\
\hline $10-14$ & $\begin{aligned}< & 10 \\
& 10-19 \\
& 20-29 \\
\geqslant & 30\end{aligned}$ & $\begin{array}{l}2024 \\
1387 \\
4048 \\
2117\end{array}$ & $\begin{array}{r}0 \\
2 \\
12 \\
9\end{array}$ & $\begin{array}{r}0.80 \\
2 \cdot 45 \\
10 \cdot 48 \\
7 \cdot 14\end{array}$ & $\begin{array}{r}0.53 \\
1.90 \\
11.85 \\
10.23\end{array}$ & $\begin{array}{r}0.53 \\
1.72 \\
11.58 \\
10.52\end{array}$ & $\begin{array}{r}0.50 \\
1.63 \\
11.33 \\
10.72\end{array}$ & $\begin{array}{r}0.58 \\
1.54 \\
10.88 \\
10.90\end{array}$ \\
\hline$\geqslant 15$ & $\begin{aligned}< & 10 \\
& 10-19 \\
& 20-29 \\
\geqslant & 30\end{aligned}$ & $\begin{array}{r}971 \\
712 \\
1573 \\
1092\end{array}$ & $\begin{array}{r}0 \\
1 \\
7 \\
10\end{array}$ & $\begin{array}{l}0.56 \\
1.35 \\
4.33 \\
3.38\end{array}$ & $\begin{array}{l}0.66 \\
1.69 \\
7 \cdot 08 \\
8 \cdot 11\end{array}$ & $\begin{array}{l}0.57 \\
1.50 \\
7.02 \\
8 \cdot 89\end{array}$ & $\begin{array}{l}0.52 \\
1.43 \\
6.97 \\
9 \cdot 26\end{array}$ & $\begin{array}{l}0.51 \\
1.30 \\
6.73 \\
9 \cdot 90\end{array}$ \\
\hline $\begin{array}{l}\text { Total } \\
\text { Deviance }\end{array}$ & & 30992 & 66 & $\begin{array}{l}65 \cdot 66 \\
53.68\end{array}$ & $\begin{array}{l}66 \cdot 10 \\
38 \cdot 42\end{array}$ & $\begin{array}{l}66 \cdot 28 \\
37 \cdot 52\end{array}$ & $\begin{array}{l}66 \cdot 01 \\
37 \cdot 20\end{array}$ & $\begin{array}{l}66 \cdot 00 \\
37 \cdot 09 \text { * }\end{array}$ \\
\hline
\end{tabular}

$\star \mathrm{df}=122$.

The combined effects of dust and smoking were assessed by fitting equation (1) to the data. For the categorised variables best fit was obtained for the model with $i=0 \cdot 72$, and for the continuous data the model with $i=0.51$ fitted best. The test of $\mathrm{H}_{0}: \lambda=0 v$ $\mathrm{H}_{\mathrm{a}}: i=1$ was significant $\left(\chi_{\mathrm{LR}}^{2}=12 \cdot 2 ; \mathrm{df}=1 ; \mathrm{p}<\right.$ 0.001 for the categorised data and $\chi_{L R}^{2}=7 \cdot 1 ; p<$ 0.01 for the continuous data), indicating that the combined effect of dust and smoking is more than additive and may be closer to being multiplicative.

The additive model with an interaction term,

$$
\log (\mathrm{RR})=\log \left\{1+\beta_{1}(\mathrm{CD} 40 \mathrm{C})+\beta_{2}(\mathrm{CYSMC})+\right.
$$

was also fitted to the data. The test of $\mathrm{H}_{0}: \beta_{3}=0 \mathrm{v}$ $\mathrm{H}_{\mathrm{a}}: \beta \neq 0$ was significant $\left(\chi_{\mathrm{LR}}^{2}=6 \cdot 2 ; \mathrm{df}=1 ; \mathrm{p}<\right.$ 0.025 ), which indicates that the interaction term is significant on the additive scale.

\section{COHORT ANALYSIS}

Table 3 shows the number of deaths and personyears for categorised dust particle-years/1000 cumulated to 1949 (CD40C) $(<5,5-9,10-14, \geqslant 15)$ and cross tabulated by years of cigarette smoking CYSMC $(<10,10-19,20-29, \geqslant 30)$. This table is collapsed over age and year at risk categories. The mean values for CYSM and CD40 are also shown for each cell. In the final analysis there were 127 cells with non-zero values for person-years. Table 3 also shows the age and year at risk adjusted SMRs calculated as a ratio between the observed and predicted number of deaths estimated from a model which included only the age and year at risk effect. Table 3 also presents the marginal RR adjusted for age, year at risk and each other exposure, and the $95^{\circ} \mathrm{CI}$ as estimated from the Poisson multiplicative model. The figure shows the SMRs plotted against dust particle-years according to each category of smoking. The increase in the dose response trend for the two highest smoking categories is apparent.

The RRs estimated by the Poisson regression are in good agreement with the results from the casereferent study. The standardised RR for dust estimated from the multiplicative model was estimated as $\exp (0.0926, \mathrm{SE} 0.0254)=1.097(95 \% \mathrm{CI}, 1.044$ $1 \cdot 153)$ for a unit of 1000 particle-years. Thus a person with exposure of 10000 particle-years during the 1940s has a 2.5 times higher risk of dying from COLD than the person with the lowest dust exposure; for a person with 20000 particle-years the risk is 6.4 times higher. This probably applies to smokers only, however, as all the cases were smokers for 10 years or more.

The combined effect of dust and smoking was assessed using equation (2). Table 4 shows the predicted numbers of deaths from the models with different values of the parameter $\lambda$. The deviance statistic indicates that the model with $i$ values ranging from 0.6 to 1.0 fit the data well. The test of $\mathrm{H}_{0}: i=0$ versus $\mathrm{H}_{\mathrm{a}}: i=1$ was significant $\left(\chi_{\mathrm{LR}}^{2}=16 \cdot 6\right.$; df $=1 ; p<0.001)$, indicating that the multiplicative model fits the data significantly better than the additive model.

Using the data from table 3 the attributable risk due to each exposure was calculated according to the method described by Kleinbaum et al ${ }^{19}$ and Bruzzi et $a l .^{20}$ The attributable risks were estimated as $64 \%$ for dust, $93 \%$ for smoking, and $98 \%$ for dust and smoking combined. Thus the approximate estimate of the proportion of cases caused by dust only is $5 \%$ 
$\left(98{ }_{0}^{\circ}-93 \%\right.$ ), by smoking only $34 \%(98 \%-64 \%)$, and by the combined exposure $59 \%(98 \%-34 \%-5 \%)$.

\section{Discussion}

The epidemiological evidence for the effect of gold mining exposure on mortality from COLD is rather inconclusive. Studies on mortality of cohorts exposed to silica have consistently shown increased mortality from non-malignant respiratory disease, largely accounted for by silicosis. ${ }^{7}$ Davis $e t$ al ${ }^{21}$ did not find an excess mortality from bronchitis in Vermont granite workers. Finkelstein $e t a^{22}$ found non-malignant respiratory disease (8th revision ICD 460-519) to be the most frequent cause of death, with SMR over 600 , among Ontario miners receiving compensation for silicosis. In a mortality study of Western Australian gold miners, the overall death rate from non-malignant respiratory disease was slightly less than expected but the death rate from silicosis was high..$^{23}$ In a previous study of mortality in middle aged South African gold miners, ${ }^{8}$ a cohort of 3971 white miners, born between 1 January 1916 and 31 December 1930, who were alive on 1 January 1970 and currently working on the gold mines, was followed up to December 1978. Standardised mortality ratios were calculated using as a reference population the total white male population of the Republic of South Africa. Increased SMR for lung cancer $(161 \cdot 2)$, chronic respiratory diseases $(165 \cdot 6)$, and acute and chronic nephritis (381.0) were reported. Of the 530 deaths found, $29(5.5 \%)$ miners had died of chronic respiratory diseases, which included bronchitis, emphysema, and pulmonary heart disease, coded according to best available information drawn from the death certificates, MBOD medical files, and necropsy findings. The RR for chronic respiratory diseases estimated from a nested casereferent study was 2.48 per unit of 10000 particleyears $(\mathrm{p}<0.03)$.

In the present mortality study, $945(43 \%)$ of the gold miners died during the follow up period from 1968-71 to 30 December 1986 at an average age of $60 \cdot 1$ years. The miners who died had significantly higher tobacco consumption measured by cigarette equivalent pack-years $(p<0.0001)$, and lower results in tests of lung function $\left(\mathrm{FEV}_{1}, \mathrm{FVC}\right.$, $\mathrm{FEF}_{25-75^{\prime \prime},} ; \mathrm{p}<0.001$ for all three tests) at the start of the follow up than the miners who survived. Those that died of COLD, however, had, in comparison to other main groups of causes of death, the lowest average values for the three tests of lung function. This suggests that for the other causes of death the lower lung function may have been a contributory factor, whereas for the COLD deaths, loss of lung function was a main cause of death. Dust particleyears were also significantly related to mortality from all causes; thus the effect of combined exposure on mortality from all causes may also be an important factor to consider. Nine miners died of pulmonary tuberculosis and they were found to have the highest exposure to dust; no miner died of pneumoconiosis.

The results from the present analysis show a statistically significant dose response relation between death from COLD and gold mining dust particle-years, after adjustment for smoking. The exposure to dust during the 1940 s was most strongly related to death from COLD. These results are in agreement with the findings from the case-referent study of emphysema, identified by necropsy in South African white gold miners. ${ }^{5}$ In that study the number of shifts worked in high dust before 1950 was most strongly related to the presence of emphysema at necropsy in men 50-70 years old who died during 1981. The authors suggested that the heavy exposure in early adulthood may be most important to the subsequent development of emphysema. The same phenomenon was seen in asbestos workers-namely that asbestos exposure received early in a man's working career was a more important determinant of subsequent air flow limitation than later exposure. ${ }^{24}$ The other possibility, which may have an effect on the results of this study, is that the concentrations of dust in the 1940s were still relatively high in comparison with those found later, even though the concentrations in the 1940 s were reportedly equal to present values. ${ }^{2}$ Becklake $e t ~ a l^{5}$ have also observed that those who had emphysema at death were slightly taller but weighed less when they entered the mining industry than those who did not develop emphysema. This finding was not confirmed by our study, where the COLD cases and referents were approximately the same height and weight at 20 years of age $(70 \mathrm{~kg})$. The subsequent five yearly increase in weight was, however, systematically higher in the referents than in the cases.

In an attempt to find out whether the cases were of a slimmer build than the referents, the radiograms taken in 1960 and 1970 were measured blindly by an independent person. The findings indicated statistically significant differences in all the measurements of lung height $(\mathrm{cm})$. The cases had significantly longer lungs in 1960 (24.5, standard deviation (SD $1.9)$, and in $1970(25.2 \mathrm{SD}, 2 \cdot 1)$ in comparison with the referents $(22 \cdot 6, \mathrm{SD} 2 \cdot 4$ and $22 \cdot 6, \mathrm{SD}, 2 \cdot 3)$. The height of the lung increased significantly for the cases but remained unchanged for the referents. The left and right lungs gave the same results. This indicates that by 1960 the lungs of the cases had already started to expand as a consequence of emphysema, and continued to do so in the 1970s; this corresponded with their increased disability and retirement from dusty occupations during the late 1960s and 1970s.

The RR for cumulative dust particle-years before 1950 , standardised for years of cigarette smoking and age estimated from the case-referent data by the 
logistic model, was $\exp (0 \cdot 1003)=1 \cdot 106$ with $95 \%$ CI (1.104-1 179) for one unit of 1000 particle-years. The estimate obtained from the cohort study was $\exp (0.0926)=1.097$ with $95 \%$ CI $1.044-1.153$. Thus for a man exposed to 17500 particle-years during the $1940 \mathrm{~s}$, the expected risk that he died of COLD when he was over 50 years of age was 5.06 times higher than for a man who was exposed to less than 5000 particle-years during the same period. As all the miners who died of COLD were smokers, however, the RR for dust most likely applies to smokers only.

For both study designs the data have indicated that the combined effect of dust and smoking is more than additive. The RR model indicated that the combined effect of the two exposures may be closer to the multiplicative model than the additive model. For the case-referent data, the mixture parameter $\lambda$ for the best fitting model was estimated to be 0.72 for the categorised data and 0.51 for the continuous data. For the cohort data the parameter $\lambda$ ranged from 0.6 to 1.0 for the best fitting models.

The results from the RR model are in line with the results presented in tables 2 and 3, which show that the RRs and SMRs for those who smoked for more than 20 years and had exposure to more than 10000 particle-years, were substantially higher than would be expected from adding the individual effects. The figure shows that the increasing trend with dust for the age and year at risk adjusted SMRs was higher for the smoking categories $20-29$ and $\geqslant 30$. Only one miner died of COLD who did not smoke cigarettes. This miner was, however, a pipe smoker of four ounces of tobacco a week over 32 years.

The relative importance of each exposure is given by the estimates of the attributable risk due to each exposure. According to those estimates, about $5 \%$ of the cases were due to the effect of dust only, $34 \%$ due to smoking only, and $59^{\circ}{ }_{0}$ due to the combined effect of dust and smoking. Thus tobacco smoking is more dangerous for workers exposed to silica dust than for unexposed people, as silica dust and tobacco smoking act synergistically in causation of obstructive lung disease.

Possible biases in this study may be related to the original selection criteria. One was a minimum of 10 years of underground exposure to gold mining. Thus miners who may have been potentially sensitive to dust, to the extent that they could die from COLD owing to the effect of dust only, may have retired from the dusty underground occupations earlier. Therefore, the healthy worker effect may be the reason why there were no deaths from COLD in those who smoked cigarettes for less than 10 years. The possibility that the cases of COLD were subjects who came for a benefit examination in 1970 was also considered. Of the 66 cases, $59 \%$ came for a periodical examination and were still working in the mine at the time of the 1970 examination, $3 \%$ came for a periodical examination but were no longer working in the mine, $27 \%$ came for a benefit examination (for compensation purposes) but were still working in the mine, and $11 \%$ came for a benefit examination and were no longer working in the mine. Thus the distribution of the number of deaths from COLD was proportionately distributed according to the reasons for attending the medical examination.

In conclusion, it appears that dust on its own does not cause disability that results in death from COLD, but smoking on its own and the combined effect of dust and smoking are the main environmental risk factors for death from COLD in the present data. Tobacco smoking is more dangerous for miners exposed to silica dust than for other men, as the two exposures act synergistically in causing chronic obstructive disease of the lung.

I thank Mrs K Guizot for measuring the radiograms, Michal Smolka for his help with the data preparation, and Dr Sluis-Cremer for his critical comments.

1 Sluis-Cremer GK. Silica exposure and silicosis in Witwatersrand gold miners in South Africa. In: Goldsmith DF, Winn DM, Shy CM, eds. Silica, silicosis, and cancer: controversy in occupational medicine. New York: Praeger, 1986:67-70.

2 Beadle DG, Bradley AA. The composition of airborn dust in South African gold mines in pneumoconiosis. In: Shapiro HA, ed. Pneumoconiosis: Proceedings of the International Conference. Johannesburg: Oxford University Press, 1970: 462-6.

3 Sluis-Cremer GK, Walters LG, Sichel HS. Ventilatory function in relation to mining experience and smoking in a random sample of miners and non-miners. $\mathrm{Br} J$ Ind Med 1967;24: 13-25.

4 Wiles FJ, Faure MH. Chronic obstructive lung disease in gold miners. In: Walton WH, ed. Inhaled Particles IV, part 2. Oxford: Pergamon Press, 1977:727-35.

5 Becklake MR, Irwig L, Kielkowski D, Webster I, De Beer M, Landau S. The predictors of emphysema in South African gold miners. Am Rev Respir Dis 1987;135:1234-41.

6 Wright JL, Harrison N, Churg A. Quartz but not iron oxide cause airflow obstruction, emphysema, and small airway lesions in the rat. Poster Session. Am Rev Respir Dis 1988; 137:49.

7 United States Department of Health and Human Services. The health consequence of smoking: chronic obstructive lung disease. $A$ report of the Surgeon General. United States Department of Health and Human Services, Public Health Service, Office on smoking and health. Rockville MD: DHHS, 1984:568. (DHHS publ No (PHS) 84-50205.)

8 Wyndham $\mathrm{CH}$, Bezuidenhout $\mathrm{BN}$, Greenacre $\mathrm{MJ}$, SluisCremer GK. Mortality in middle aged South African gold miners. Br J Ind Med 1986;43:677-84.

9 Beadle DG. The relationship between the amount of dust breathed and the development of radiological signs of silicosis: an epidemiological study of South African gold miners. In: Walton WH, ed. Inhaled Particles III. Oxford: Pergamon Press, 1971:953-64.

10 Liddell FDK, McDonald JC, Thomas DC. Methods of cohort analysis: Appraisal by application to asbestos mining. Journal of the Royal Statistical Society (A) 1977;140:469-91.

11 Whittemore AS, McMillan A. Lung cancer mortality among US uranium miners: a reappraisal. J Natl Cancer Inst 1983;71: 489-99.

12 Breslow NE, Storer BE. General relative risk functions for casecontrol studies. Am J Epidemiol 1985;122:149-62.

13 Moolgavkar SH, Venzon DJ. General relative risk regression models for epidemiological studies. Am J Epidemiol 1987;126: 949-61. 
14 Breslow NE, Day NE. Statistical methods in cancer research, Vol II The design and analysis of cohort studies. Lyon: International Agency for Research on Cancer, 1987.

15 Lubin JH, Gaffey W. Relative risk models for assessing the joint effects of multiple factors. Am J Ind Med 1988;13:149-67.

16 James F, Roos M. "MINUIT"-A system for function minimization and analysis of the parameter errors and correlations. Computer Physics Communications 1975;10:343-67.

17 Frome EL, Checkoway $\mathrm{H}$. Use of poisson regression models in estimating incidence rates and ratios. Am J Epidemiol 1985; 121:309-23.

18 Berry G. Dose-response in case-control studies. J Epidemiol Community Health 1980;34:217-22.

19 Kleinbaum DG, Kupper LL, Morgenstern H. Epidemiologic research: principles and quantitative methods. Belmont, California: Lifetime Learning Publications, 1982.

20 Bruzzi P, Green SB, Byar DP, Brinton LA, Schairer C Estimating population attributable risk for multiple risk factors using case-control data. Am J Epidemiol 1985;122: 904-14.

21 Davis LK, Wegman DH, Monson RR, Froines J. Mortality experiencer of Vermont granite workers. Am J Ind Med 1983; 4:705-23.

22 Finkelstein M, Liss GM, Krammer F, Kusiak RA. Mortality among workers receiving compensation awards for silicosis in Ontario 1940-85. Br J Ind Med 1987;44:588-94.

23 Armstrong BK, McNulty JC, Levitt LJ, Williams KA, Hobbs MST. Mortality in gold and coal miners in Western Australia with special reference to lung cancer. $\mathrm{Br} J$ Ind Med 1979;36: 199-205.

24 Copes RL, Thomas D, Becklake MR. Temporal patterns of exposure and nonmalignant pulmonary abnormality in Quebec chrysotile workers. Arch Environ Health 1985;40: 80-6.

Accepted 19 March 1990

\section{Correspondence and editorials}

The British Journal of Industrial Medicine welcomes correspondence relating to any of the material appearing in the journal. Results from preliminary or small scale studies may also be published in the correspondence column if this seems appropriate. Letters should be not more than 500 words in length and contain a minimum of references. Tables and figures should be kept to an absolute minimum. Letters are accepted on the understanding that they may be subject to editorial revision and shortening.

The journal now also publishes editorials which are normally specially commissioned. The Editor welcomes suggestions regarding suitable topics; those wishing to submit an editorial, however, should do so only after discussion with the Editor. 